\title{
Preparation and characterization of porous alumina ceramics using sunflower seed shells as fugitive material
}

\section{(Preparação e caracterização de cerâmica de alumina porosa utilizando casca de semente de girassol como material fugitivo)}

\author{
J.Alzukaimi ${ }^{1 *}$, R. Jabrah ${ }^{1}$ \\ ${ }^{I}$ Higher Institute for Applied Sciences and Technology, Damascus, Syria
}

\begin{abstract}
Porous alumina ceramics were prepared through the space holder technique, using ground sunflower seed shells as a fugitive material and uniaxial pressing for forming the green ceramics. Influences of the sunflower seed shell content on the shrinkage of the green bodies and porosity of sintered products were evaluated. The prepared ceramics were characterized for mechanical properties using the Brazilian disk test, and the porosity effect on the measured strength was determined. The microstructure was characterized by SEM. The sunflower seed shell content was varied from 0 to $60 \mathrm{wt} \%$. Porosities within $29.9-71.0$ vol\% were achieved, and the strength of the obtained alumina ceramics decreased accordingly from 59.7 to $4.0 \mathrm{MPa}$. Additional samples, prepared with different compaction pressure, were characterized for electrical properties and showed high electrical insulation capability, which increased with porosity. Mechanical and electrical data were discussed based on theoretical models, namely the Gibson-Ashby model and/or the minimum solid area model.

Keywords: alumina, porous materials, fugitive material, mechanical properties, solid-state synthesis.
\end{abstract}

\section{Resumo}

Cerâmica porosa de alumina foi preparada pela técnica de queima de orgânico, usando cascas de sementes de girassol moídas como material fugitivo e prensagem uniaxial para conformação do corpo verde. Foram avaliadas as influências do teor de casca de semente de girassol na retração do corpo verde e na porosidade das peças sinterizadas. As cerâmicas preparadas foram caracterizadas quanto às propriedades mecânicas usando o ensaio de compressão diametral e o efeito da porosidade na resistência mecânica foi determinado. A microestrutura foi caracterizada por MEV. O teor de casca de semente de girassol variou de 0 a $60 \%$ em massa. Porosidades de 29,9-71,0\% em volume foram alcançadas, e a resistência das cerâmicas de alumina obtidas diminuiu de 59,7 para 4,0 MPa. Amostras adicionais, preparadas com diferente pressão de compactação, foram caracterizadas quanto às propriedades elétricas e apresentaram alta capacidade de isolamento elétrico que aumentou com a porosidade. Os dados mecânicos e elétricos foram discutidos com base nos modelos teóricos de Gibson-Ashby elou área sólida mínima.

Palavras-chave: alumina, materiais porosos, material fugitivo, propriedades mecânicas, síntese em estado sólido.

\section{INTRODUCTION}

Porous ceramics combine two types of properties: the first is inherited from the solid ceramic phase, such as high melting temperature, chemical and thermal stability, high corrosion resistance, high mechanical strength, and biocompatibility, and the second is associated with the features gained from the addition of the pores, such as reduced density, increased surface area, high fluid permeability, reduced thermal conductivity, reduced dielectric constant, and increased specific strength [1-3]. As a result, these materials find an increasing demand for use in relevant applications where such a combination of properties is mandatory or more efficient than other alternatives. Examples include high-

*julianzukaimi@yahoo.com

Dhttps://orcid.org/0000-0002-4376-9456 temperature insulation, molten metal and hot corrosive gas and liquid filtration, catalyst supports, biomaterials, metal and polymer matrix composites, absorbents, chemical sensors, electrodes for fuel cells, lightweight structural materials, and gas combustion burners [1-5]. Several routes for the creation of pores inside ceramics can be found in the literature. While partial sintering of powder compacts being the simplest [1], the replica technique is considered the most conventional processing method for the fabrication of porous ceramics [3, $6,7]$, where a polymeric sponge is immersed in a ceramic slurry, followed by squeezing, drying, heat treatment for removing the sponge template, and sintering of the ceramic coating $[1,3,5,8,9]$. However, since the obtained structure is a positive copy of the original sponge template, the removal of the template usually leaves flaws that lead to poor mechanical properties. As opposed to this method, the sacrificial phase method produces a porous structure that is a negative copy of the used template (i.e., the sacrificial phase), and therefore, no 
flaws are caused by template removal $[8,9]$. This method is based on the mixing of the ceramic powder, or its precursors, with a fugitive material which acts as a pore-forming agent (space holder or pore former, abbreviated PF henceforth), followed by the formation of a green body, extraction of the $\mathrm{PF}$, and sintering of the ceramic phase. A variety of PFs has been used: 1) solid organics (natural and synthetic), such as cellulose, wax, carbon black, sawdust, beads (PVC, PMMA, PS) and nylon, which are removed by pyrolysis $[1,7,10]$; 2) liquids, such as water and volatile oils, the removal of which is done by sublimation [1,9]; 3) salts, being removed by washing with water [1, 11]; and 4) metals, which are leached with acids $[1,10,11]$. Further uncommon biopolymeric PFs, such as yeast, fine flour, coffee, and poppy seeds, were tried by other researchers [11, 12]. Ali et al. [12] used commercial rice husk ash and Ribeiro et al. [13] used commercial rice husk as PFs for the fabrication of porous alumina ceramics. Waste materials such as paper pulp waste and primary battery graphite waste were tried as well [12]. The use of waste material is a promising choice for obvious economic and ecological reasons, and the search for new sources is still in progress [12].

In this study, a new waste material of biological origin, namely sunflower seed shells (hulls or husks), is suggested. Sunflower seed shells are composed mostly of cellulose and other organic materials, with sufficiently little ash content (up to 2.1-2.7 wt \%) [14, 15]. After consumption of the kernels, the shells are either burned as a biomass fuel [16] or thrown away as a by-product or waste. Other possible uses are reported $[17,18]$. In 2018/2019, global production of sunflower seeds was 51.46 million tons, led by Ukraine with $29 \%$ and Russia with $25 \%$ of the world total. European Union, Argentina, and Turkey also contributed significant volumes [19]. Therefore, being abundant and low in both ash and cost, sunflower seed shells constitute a direct solid and cheap candidate as a poreforming agent for the fabrication of porous ceramic materials using the sacrificial phase route and the solid-state processing.

Among other ceramic materials, alumina has major importance as raw material and is widely used for the production of traditional and advanced ceramics, both dense and porous, that fulfill the needs of a variety of applications [20-22]. The aim of the present work was to study the potential use of sunflower seed hulls as a solid PF for the fabrication of porous alumina ceramics by the sacrificial phase method and the solid-state processing route, and to characterize the obtained alumina ceramics for physical, mechanical, and electrical properties. The use of sunflower seed hulls as a pore-forming agent preserves the ceramic solid-state processing without any further complication and benefits from its abundance and low cost. So far, no report on the use of this material (i.e., sunflower seed hulls) as a pore-forming agent for the fabrication of porous alumina ceramics appears to have been published yet.

\section{EXPERIMENTAL PROCEDURE}

Materials: aluminum oxide G, neutral, for thin-layer chromatography (TLC, with maximum limits of impurities of $0.02 \%$ iron and $0.012 \%$ chloride) from Himedia, was heattreated at $1300{ }^{\circ} \mathrm{C}$ for $1.5 \mathrm{~h}$ and the obtained powder was used as the starting ceramic raw material. Sunflower seeds were purchased from the domestic market and handpicked to remove the kernels. The obtained shells were collected and soaked in hot distilled water for $2 \mathrm{~h}$ to dissolve the remaining salt. After several soaking and washing cycles, they were left to air dry for 3 days, then dried at $150{ }^{\circ} \mathrm{C}$ for $24 \mathrm{~h}$, and subsequently ground using an ordinary coffee grinder, and finally sieved to a particle size $\leq 250 \mu \mathrm{m}$ in a 60 mesh screen. Polyvinyl alcohol, fully hydrolyzed (MW approx. 60000) for synthesis, from Merck, was dissolved in hot distilled water for the preparation of an $8 \mathrm{wt} \%$ polyvinyl alcohol (PVA) binder in the form of an aqueous solution.

Sample preparation: the PF ground sunflower seed shells (SSS) were mixed with the alumina powder at contents of $0,20,40$ and $60 \mathrm{wt} \%$. Then, proper amounts of the binder were added stepwise (5-15 drops a time) and thoroughly blended in an agate mortar and pestle for the 4 alumina/SSS mixtures to obtain 4 pastes. Drying the pastes was conducted at $100{ }^{\circ} \mathrm{C}$ in a dryer (Memmert) for $24 \mathrm{~h}$. It was found that the binder amount required for obtaining a paste increased with the increase in the SSS content, and the PVA content varied accordingly as 3.4, 6.5, 8.5 and 10.5 $\mathrm{wt} \%$ in the dry pastes. Next, the dry pastes were ground in the agate mortar and sieved to a particle size $<250 \mu \mathrm{m}$, using a 60 -mesh screen. To make pellets, the resulting ground powders were pressed in hardened stainless steel die $(10 \mathrm{~mm}$ in diameter), at a pressure of $125 \mathrm{MPa}$, using a manually operated hydraulic press (Graseby Specac, maximum load of 15 tons). Ejection was done without lubrication, and the die was cleaned with acetone. For each SSS content, 7 disks, $5 \mathrm{~mm}$ thick, were prepared. After drying for $24 \mathrm{~h}$ at $100{ }^{\circ} \mathrm{C}$, the disks were sintered in a programmable electrical resistance heating furnace (Lenton Furnaces) according to a predefined thermal cycle up to $1500{ }^{\circ} \mathrm{C}$ for $2 \mathrm{~h}$. Cooling was performed by switching off the furnace. A sintering temperature of $1500{ }^{\circ} \mathrm{C}$ was chosen in order to minimize grain growth and to avoid significant elimination of pores. In order to allow for a volume electrical resistivity measurement using available equipment, additional bigger size alumina disks were prepared by the same procedure, but with the following settings: SSS contents of $0,5,10$ and $15 \mathrm{wt} \%$, a $70 \mathrm{~mm}$ diameter die, and a pressing load of 15 tons (i.e., a pressure of about $38 \mathrm{MPa}$ ).

Characterization. X-ray diffraction (XRD) test: the crystalline structures of the as-received alumina powder, before and after the heat treatment, and some of the obtained alumina ceramic samples were characterized by XRD using a diffractometer (Philips, PW3710, Bragg-Brentano $\theta-2 \theta$ ), having a negligible instrumental broadening, operating at $40 \mathrm{kV}$, and $30 \mathrm{~mA}$ with a $\mathrm{CuK} \alpha$ radiation $(\lambda=1.5406 \AA)$; a range of $2 \theta=20-70^{\circ}$ was scanned at a rate of $0.02 \%$. Thermogravimetry and differential scanning calorimetry (TGA/DSC) analysis: in order to design the thermal cycle for the sintering of the prepared green alumina ceramic 
disks, the thermal behavior of the used SSS was studied by TGA/DSC analysis using a thermal analyzer (Setaram Instr., France) at a heating rate of $5{ }^{\circ} \mathrm{C} / \mathrm{min}$ up to $950{ }^{\circ} \mathrm{C}$ in ambient air. The untreated alumina was also studied by thermogravimetry at the rate of $10^{\circ} \mathrm{C} / \mathrm{min}$ up to $1300{ }^{\circ} \mathrm{C}$ to account for its mass and phase change during heat treatment. Particle size measurement of SSS powder: the SSS powder, sieved to a particle size $\leq 250 \mu \mathrm{m}$, was dispersed in distilled water and characterized for its particle size distribution using a Mastersizer 2000E instrument (Malvern, UK). Optical microscopy examination of SSS powder: transmission and reflection metallurgical microscope equipped with a camera (XJZ-6 Upright, China) was used to examine the morphology of the SSS powder, which was sieved with a 60 mesh screen and manually dispersed over a flat glass slide without any additional treatment. Shrinkage and porosity measurements: linear and volumetric shrinkages of the prepared disk samples were calculated by:

$$
\text { Shrinkage }(\%)=\frac{\mathrm{G}_{\mathrm{AS}}-\mathrm{G}_{\mathrm{BS}}}{\mathrm{G}_{\mathrm{BS}}} .100
$$

where $G$ refers to the sample diameter (for the radial shrinkage), thickness (for the vertical shrinkage), or volume (for the volumetric shrinkage) and subscript BS and AS refer to the sample before and after sintering, respectively. The overall porosity $(\mathrm{P})$ was calculated by:

$$
\mathrm{P}=1-\frac{\rho_{\mathrm{b}}}{\rho_{\mathrm{s}}}
$$

where $\rho_{\mathrm{b}}$ is the bulk density, and $\rho_{\mathrm{s}}$ is the density of the solid ceramic phase. Dimensions and mass of the prepared disks (after sintering) were used to determine $\rho_{\mathrm{b}}$, and a value of $3.96 \mathrm{~g} / \mathrm{cm}^{3}$ was taken for $\rho_{\mathrm{s}}[23,24]$ since the solid phase of the prepared porous alumina samples was composed of $\alpha-\mathrm{Al}_{2} \mathrm{O}_{3}$, as shown later by the XRD result and the very little residual ash content confirmed by TGA test. Open porosity was measured using the Archimedes principle, following the ASTM C20 procedure [25]. The closed porosity is the difference between the total and open porosities. Microstructure evaluation: the obtained porous alumina ceramic disks were observed by the scanning electron microscopy (SEM), in order to characterize the morphology of the pores. An SEM instrument (Tescan, Vega-II XMU5136, USA) was used, and the micrographs were taken by examining the cross-sectional areas $\left(12 \mathrm{~mm}^{2}\right.$ on average $)$ of 4 specimens, each representing one SSS content. Fresh surfaces were prepared by breaking the disks immediately before the test. Mechanical property characterization: indirect tensile strength of the sintered porous alumina ceramic samples, designed for mechanical characterization, was determined through the Brazilian disk test method. This method is suited for brittle materials like rocks and ceramics. It is based on the diametrical compression (until fracture) of a cylindrically shaped test sample, which creates a tensile stress field indirectly applied across the diametrical plane [26-28]. The mechanical property provided is the indirect tensile strength (also called the splitting tensile strength, because of the fracture shape) given by:

$$
\sigma_{\mathrm{s}}=\frac{2 . P_{\mathrm{m}}}{\pi \cdot \mathrm{D} \cdot \mathrm{t}}
$$

where $\mathrm{P}_{\mathrm{m}}$ is the maximum force at fracture, and $\mathrm{D}$ and $\mathrm{t}$ are the diameter and thickness of the cylinder, respectively. Breaking of the prepared disks ( 7 samples for each of the 4 SSS compositions, a total of 28 samples) was conducted using universal materials testing machine (Adamel Lhomargy, DY34; capacity of $10 \mathrm{kN}$ ) with a displacement rate of $0.5 \mathrm{~mm} / \mathrm{min}$. The obtained data were analyzed by the Weibull statistics, based on a linear fitting of $\ln \left[\ln \left(1 / \mathrm{P}_{\mathrm{s}}\right)\right]$ versus $\ln \sigma_{s}$, where $P_{s}$ is the survival probability. To calculate this probability for a given series of $\mathrm{N}$ equivalent samples, the samples were first ranked in order of increasing strength, then the relation $P_{s}=1-n /(N+1)$ was applied, where $n=1,2, \ldots, N$ is the sample rank. The Weibull statistics entails two parameters: characteristic strength and Weibull modulus. The characteristic strength $\left(\sigma_{0}\right)$ corresponds to a probability of survival $P_{s}=1 / \mathrm{e}$ $(\approx 0.37)$. The Weibull modulus $(\mathrm{m})$ is the slope of the fitted straight line of $\ln \left[\ln \left(1 / \mathrm{P}_{\mathrm{s}}\right)\right]$ as a function of $\ln \sigma_{\mathrm{s}}$. It indicates how rapidly the strength falls when approaching $\sigma_{0}$ (the higher the $m$ value, the lower is the variability of strength). In terms of the flaws within the material under test, it provides an estimation of the narrowness of their size distribution: a high $\mathrm{m}$ corresponds to a narrow flaw size distribution and, therefore a low scattering of the strength [29-31]. In all the measurements concerning the splitting tensile strength, shrinkage, and porosity, the average of 7 results was taken and their standard deviation was used to estimate the experimental error. Electrical property characterization: DC resistance of 4 disk samples was indirectly measured, using a circular electrode for the measurement of the surface and volume resistivity of solid electrical insulators connected to a high resistance meter (megohmmeter, HP, 4329A). DC voltages of 500 and $1000 \mathrm{~V}$ were applied. Dimensions of the electrode and thickness of each sample were used to determine the volume electrical resistivity according to the ASTM-D257-07 standard [32].

\section{RESULTS AND DISCUSSION}

Characterization of the starting alumina: the XRD pattern of the as-received alumina (before heat treatment) is given in Fig. 1a. Comparison with the XRD pattern of boehmite $(\gamma$-AlOOH, JCPDS 21-1307) indicated a matching of 10 diffraction peaks [20]. Three peaks at $2 \theta=31.38^{\circ}$, $45.58^{\circ}$, and $67^{\circ}$ were related to $\gamma-\mathrm{Al}_{2} \mathrm{O}_{3}$ (JCPDS 10-0425) [33], although the last two peaks $\left(2 \theta=45.58^{\circ}\right.$ and $\left.67^{\circ}\right)$ are shared with boehmite. The peak at $2 \theta=25.44^{\circ}$ might be attributed to $\alpha-\mathrm{Al}_{2} \mathrm{O}_{3}$ (JCPDS 42-1468) [20, 23, 33]. These results suggested that the as-received alumina (untreated) was possibly constituted of a mixture of an aluminum oxyhydroxide, boehmite, and some additional transition alumina phases. The identified boehmite structure of the untreated alumina was not well crystallized, as indicated by the wideness and low intensity of the matched peaks, 
especially for $2 \theta \geq 35^{\circ}$. This alumina was found to have lost a significant amount of its weight (about 14\%) by heat treatment, as demonstrated later by the TGA result, meaning that it could not be composed purely of transition aluminas. The dehydration of boehmite is described by:

$$
2 \mathrm{AlOOH} \rightarrow \mathrm{Al}_{2} \mathrm{O}_{3}+\mathrm{H}_{2} \mathrm{O}
$$

corresponding to a weight loss of $15 \mathrm{wt} \%$. This is consistent with the XRD result detailed above. Fig. 1b shows the XRD pattern of the as-received alumina after heat treatment at $1300{ }^{\circ} \mathrm{C}$. The $\alpha-\mathrm{Al}_{2} \mathrm{O}_{3}$ phase peaks were well recognized (JCPDS 42-1468) [20, 23, 33]. However, additional peaks were present as well. These were associated with nonalpha alumina phases that remained due to incomplete transformation after the above-mentioned heat treatment. For instance, the peaks at $2 \theta=21.98^{\circ}, 23.66^{\circ}, 24.52^{\circ}$, $27.26^{\circ}, 27.92^{\circ}, 29.02^{\circ}, 36.16^{\circ}$, and $58.64^{\circ}$ were associated with $\delta-\mathrm{Al}_{2} \mathrm{O}_{3}$ (ICDD 16-0394) [33], while those at $2 \theta=$ $31.4^{\circ}$ and $36.9^{\circ}$ were related to $\theta-\mathrm{Al}_{2} \mathrm{O}_{3}$ (JCPDS 35-0121) [33]. The peaks at $2 \theta=32.16^{\circ}, 34.12^{\circ}, 39.34^{\circ}, 44.98^{\circ}$, $46.14^{\circ}$, and $67.28^{\circ}$ seem common to these two transition alumina phases. After sintering of this $1300{ }^{\circ} \mathrm{C}$ heat-treated alumina at $1500{ }^{\circ} \mathrm{C}$, all these peaks related to the transition

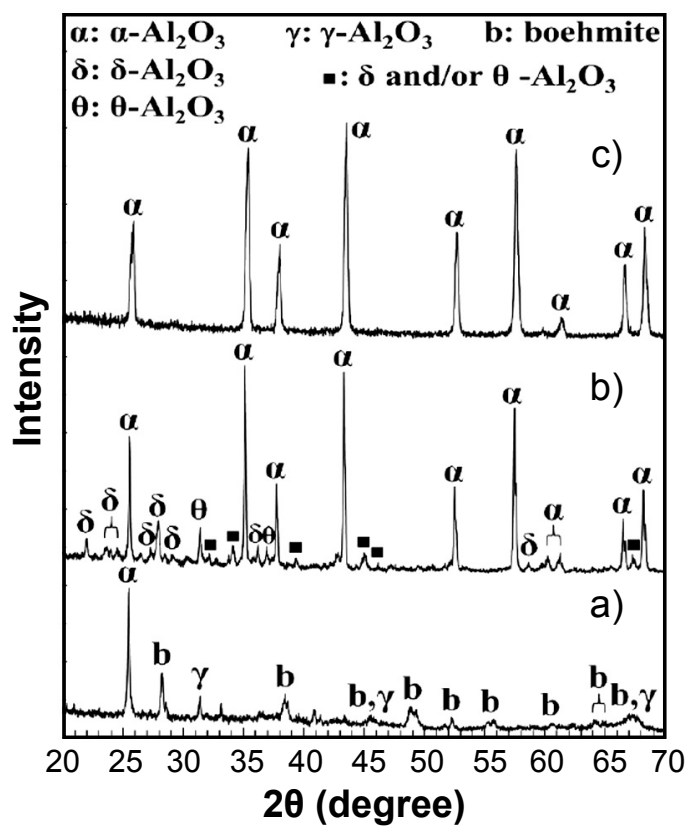

Figure 1: XRD patterns of: a) as received untreated alumina powder; b) raw alumina after heat treatment of the as-received alumina (heating rate of $10{ }^{\circ} \mathrm{C} / \mathrm{min}$, in ambient air, at $1300^{\circ} \mathrm{C}$ for $90 \mathrm{~min}$ ), used for the preparation of the porous alumina ceramic samples; and c) sintered product obtained using $60 \mathrm{wt} \%$ of ground sunflower seed shells (SSS).

[Figura 1: Padrões de DRX de: a) pó de alumina como recebido, não tratado; b) alumina de partida após tratamento térmico da alumina recebida (taxa de aquecimento de $10{ }^{\circ} \mathrm{C} / \mathrm{min}$, ao ar, a $1300{ }^{\circ} \mathrm{C}$ por $90 \mathrm{~min}$ ), utilizada na preparação das amostras de cerâmica de alumina porosa; e c) produto sinterizado obtido utilizando $60 \%$ em massa de cascas de sementes de girassol moídas (SSS).] alumina phases disappeared completely, and a mass change of 1-2 wt $\%$ was observed. This confirmed that the heat treatment of the starting raw alumina up to $1300{ }^{\circ} \mathrm{C}$ was not sufficient to achieve complete conversion to $\alpha-\mathrm{Al}_{2} \mathrm{O}_{3}$. Fig. $1 \mathrm{c}$ corresponds to the XRD pattern of the sintered pellets, prepared with an SSS content of $60 \mathrm{wt} \%$. The corundum $\left(\alpha-\mathrm{Al}_{2} \mathrm{O}_{3}\right)$ crystalline structure was well identified (JCPDS 42-1468) [20, 23, 33]. No additional peaks other than the $\alpha-\mathrm{Al}_{2} \mathrm{O}_{3}$ phase peaks were present. This proved that the phase transformation into $\alpha-\mathrm{Al}_{2} \mathrm{O}_{3}$ was completed during the sintering process and justified the later use of the value of $3.96 \mathrm{~g} / \mathrm{cm}^{3}$ as the density $\rho_{\mathrm{s}}$ (theoretical density) of the solid phase in the prepared porous alumina samples [23,24], required for the calculation of the total porosity $\mathrm{P}$.

Heat treatment and thermal cycle selection: the thermogravimetric analysis of the as-received alumina (before heat treatment) is given in Fig. 2a; a weight loss of $14 \mathrm{wt} \%$ was measured, which is expected to be associated with the removal of adsorbed and structural water (i.e., moisture removal and dehydration of boehmite [20]). The thermal analysis results, TGA and DSC, for the used SSS are shown in Figs. $2 b$ and $2 c$, respectively. The SSS lost more than $98 \%$ of its weight at $950{ }^{\circ} \mathrm{C}$. The main loss occurred between 250 and $450{ }^{\circ} \mathrm{C}$, as revealed by the large exothermal DSC peak, which was related to the burning of organic material. Although more than $70 \%$ of this weight was lost at around $450{ }^{\circ} \mathrm{C}$, weight loss continued up to 950 ${ }^{\circ} \mathrm{C}$. This was somewhat in agreement with the findings of Haykiri-Acma et al. [15], who obtained a completion of the weight loss by about $900^{\circ} \mathrm{C}$ for the SSS they used. Based on the obtained SSS thermal analysis result, it was suggested that a burn-off temperature of $950{ }^{\circ} \mathrm{C}$ would be sufficient for the removal of all organic material, whether from the SSS or the binder since the PVA binder should burn much earlier. Therefore, the thermal cycle adopted for the sintering of the prepared alumina green bodies was as follows: heating at a rate of $5{ }^{\circ} \mathrm{C} / \mathrm{min}$ from room temperature to $950{ }^{\circ} \mathrm{C}$, with

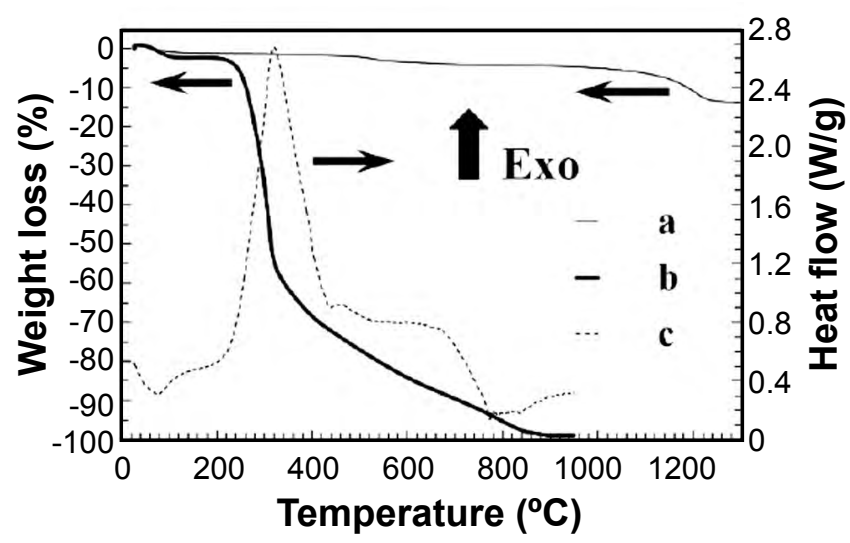

Figure 2: TGA curve (a) of the as-received untreated alumina powder (heating rate of $10^{\circ} \mathrm{C} / \mathrm{min}$, in ambient air); and TGA (b) and DSC (c) curves of the used SSS (heating rate of $5^{\circ} \mathrm{C} / \mathrm{min}$, in ambient air). [Figura 2: Curva de TGA (a) do pó de alumina como recebido, não tratado (taxa de aquecimento de $10{ }^{\circ} \mathrm{C} / \mathrm{min}$, ao ar); e curvas de TGA (b) e DSC (c) de SSS usado (taxa de aquecimento de $5{ }^{\circ} \mathrm{C} / \mathrm{min}$, ao ar).] 
a dwell time of $1 \mathrm{~h}$ for organics removal, followed by a heating at a rate of $10^{\circ} \mathrm{C} / \mathrm{min}$ up to the sintering temperature of $1500{ }^{\circ} \mathrm{C}$, with a dwell time of $2 \mathrm{~h}$; then, the furnace was switched off for cooling. According to the TGA result of the SSS, a total of $1.42 \mathrm{wt} \%$ residual ash was observed. Since the alumina in the green samples lost no more than $2 \mathrm{wt} \%$ during the sintering, it may be estimated that the samples prepared using the highest SSS content of $60 \mathrm{wt} \%$ contained no more than $2.2 \mathrm{wt} \%$ of residual ashes.

Particle size distribution of sunflower seed shell powder: the particle size distribution curve of the used SSS is shown in Fig. 3a. Usual percentile readings of d $10=15 \mu \mathrm{m}, \mathrm{d} 50=89$ $\mu \mathrm{m}$, and $\mathrm{d} 90=275 \mu \mathrm{m}$ were observed, with a residual weight of $0.35 \% .9 .6 \mathrm{vol} \%$ of the analyzed sample was found to be above $250 \mu \mathrm{m}$, which may be explained by a swelling effect of the SSS with the dispersant water and/or agglomeration of its particles since it was sieved to a particle size less than $250 \mu \mathrm{m}$, or could suggest that the measured sizes of the SSS particles were overestimated. The wide size distribution curve shown in Fig. 3a suggested that the used ground SSS was composed of particles with a wide size range. Microscopy evaluation of sunflower seed shells powder: the particle shape of the used SSS powder was analyzed by optical microscopy (Fig. 3b). Randomly shaped SSS particles with size up to about $400 \mu \mathrm{m}$ were seen. The large lumps corresponded to agglomerates of individual particles since the SSS powder was sieved using a 60 mesh screen. Large grains, as well as small ones, were seen, and the used SSS particle size varied over a wide range.

Linear and volumetric shrinkage: Fig. 4 shows the linear and volumetric shrinkages of the prepared alumina ceramic samples. Shrinkage of fired ceramic bodies is the sum of several contributions: 1) weight loss due to water removal and organic material burnout; 2) change in the density of the ceramic powder material caused by a phase transformation, if any; and 3) sintering process if at least one densifying mechanism is active. Shrinkage increased with the increase in the SSS content, which was in line with other studies $[4,12]$. It was noted that the vertical and radial shrinkages (i.e., shrinkage of the thickness and diameter of the pellet, respectively) were equal for an SSS content $\leq 40$ wt \%, whereas the former was somewhat lower for a SSS content of $60 \mathrm{wt} \%$. Although this effect was not clearly observed until a high SSS content was attained, a possible qualitative explanation is suggested: the uniaxial pressure used for the compaction of the pellets was vertically applied, thereby bringing the alumina and the SSS particles closer to each other more in the direction of the pressure than in the transversal one. Therefore, after removal of the SSS, more empty space was available along the radius for the alumina particles to contact each other, leading to an increase in the radial shrinkage. The increase in shrinkage as the SSS content increased is expected to be caused by the removal of more organics introduced by the SSS material and by the binder. The moderately high volumetric shrinkage value of $31 \%$ for the sample prepared with no SSS and with a small binder amount of $3.4 \mathrm{wt} \%$ may indicate a slight increase in
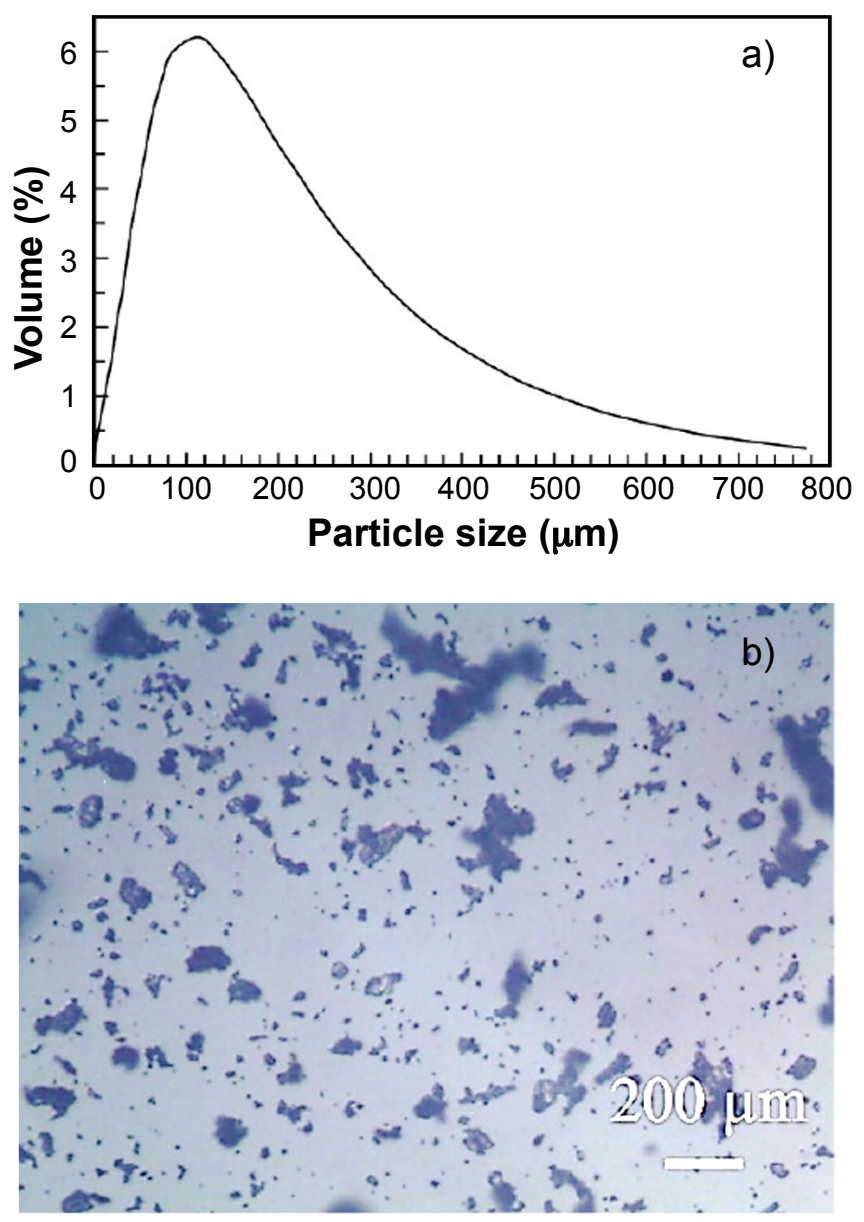

Figure 3: Particle size distribution curve (a) and optical micrograph (b) of the used SSS.

[Figura 3: Curva de distribuição do tamanho de partícula (a) e micrografia óptica (b) de SSS usado.]

the density of the alumina phase, since its transformation into $\alpha-\mathrm{Al}_{2} \mathrm{O}_{3}$ was not complete after heat treatment at 1300 ${ }^{\circ} \mathrm{C}$, as shown by Figs. $1 \mathrm{~b}$ and $1 \mathrm{c}$. The densification role of the SSS-free alumina sample was not expected to be significant since, in this case, the sintered alumina was highly pure, and the sintering temperature of $1500{ }^{\circ} \mathrm{C}$ was rather low. The former argument would apply to all the other non-zero SSS alumina samples since the same alumina was used in their preparation, whereas the latter may not be true as the residual ashes (i.e., impurities) from the SSS material (2.2 $\mathrm{wt} \%$ ) could activate some densifying mechanisms, thereby adding another contribution to the shrinkage. For instance, it is interesting to report that SSS usually includes a high content of silica [18].

Porosity measurement: total porosity, along with the open porosity, increased with the increase in the SSS content, as shown in Figs. 5a and 5b. Porosity may correspond to the space left by the imperfect packing of the randomly-shaped alumina particles in the green compact, as well as to the pores possibly contained inside these particles, or could be created by the burnout of the organic matter from the PF (pore former) and/or the binder, or by the removal of the remaining hydroxyl groups in the incompletely transformed heat- 


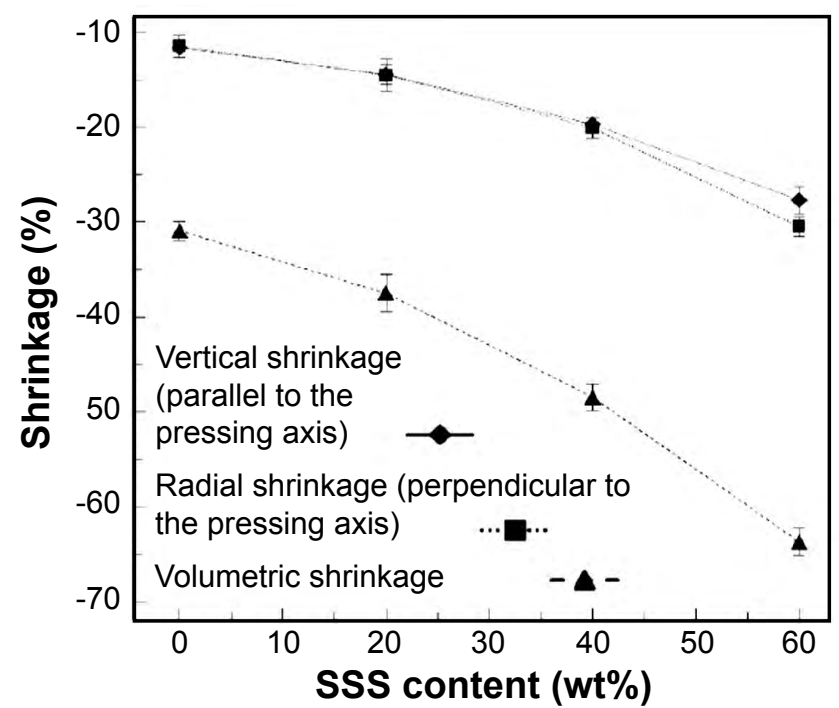

Figure 4: Linear shrinkage (along radius and thickness) and volume shrinkage of the alumina ceramic pellets versus SSS content in the green body.

[Figura 4: Retração linear (ao longo do raio e da espessura) e retração do volume dos discos de alumina versus teor de SSS no corpo verde.]

treated alumina. Since the increase in the SSS content led to an increase in its volume, the porosity increased. However, porosity and SSS content were not linearly proportional due to the concurrent shrinkage, as can be seen in Fig. 4. This effect can be viewed by noting that an increase of $20 \mathrm{wt} \%$ in the SSS content, from 0 to $20 \%$, yielded an increase of $21.3 \mathrm{vol} \%$ in the total porosity, whereas the same increase from 40 to $60 \mathrm{wt} \%$ in the SSS content yielded an increase of only $7.8 \mathrm{vol} \%$ in the total porosity. The closed porosity (i.e., the difference between the total and open porosities) ranged from 6.4 to 7.5 vol\%, which was small compared with the total porosity, and was basically independent from the SSS content (Fig. 5c), suggesting that it might be associated with pores inside the alumina particles (or created by its dehydration), and the resulting overall porosity was mainly open. Another possibility is an underestimated value for the open porosity provided by the ASTM C20 procedure. Regarding the large porous alumina disk samples (prepared for the electrical resistivity measurement under the same conditions except for the smaller compaction pressure of 38 $\mathrm{MPa}$ ), it was observed that only decreasing the compaction pressure allowed the achievement of $58.3 \mathrm{vol} \%$ porosity with only $15 \mathrm{wt} \%$ SSS content, which was nearly equivalent to $40 \mathrm{wt} \%$ SSS content at a compaction pressure of 125 $\mathrm{MPa}$, as can be verified by Figs. 5d and 5a, respectively.

Microstructure characterization: Fig. 6 shows the SEM micrographs of the cross-sectional surfaces of 4 porous alumina samples, prepared by breaking the pellets immediately before the examination. The obtained microstructure was rather simple to describe. For all SSS contents, Figs. 6A1, 6B1, 6C1, and 6D1 show a distribution of randomly shaped pores within a partially sintered solid alumina matrix. Figs. 6A3, 6B3, 6C3 , and 6D3 demonstrate the randomly shaped alumina particles, of sizes ranging

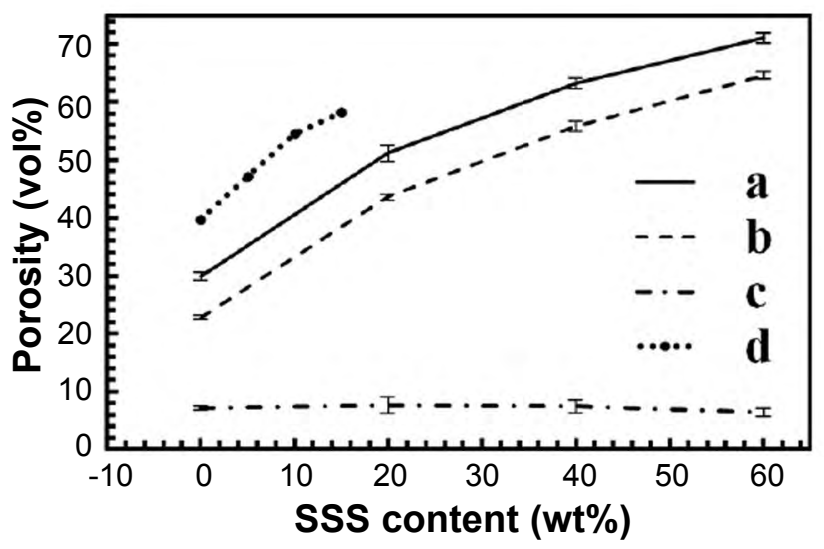

Figure 5: Total (a), open (b), and closed (c) porosity of small alumina ceramic pellets (compacted at $125 \mathrm{MPa}$ ), and total porosity (d) of large disks (compacted at $38 \mathrm{MPa}$ ) versus the SSS content in the green bodies.

[Figura 5: Porosidade total (a), aberta (b) e fechada (c) de pequenos discos de alumina (compactados a $125 \mathrm{MPa}$ ) e porosidade total (d) de discos grandes (compactados a $38 \mathrm{MPa}$ ) versus o teor de SSS nos corpos verdes.]

from less than $1 \mu \mathrm{m}$ and up to about $5 \mu \mathrm{m}$. For the sample prepared with 0\% SSS, the macropores observed in Figs. $6 \mathrm{~A} 2$ and $6 \mathrm{~A} 3$, with sizes of up to about $13 \mu \mathrm{m}$, were related to the poor packing or the aggregates of the irregularly shaped alumina particles in the green body or may result from the burnout of the PVA binder, although its content was small, only $3.4 \mathrm{wt} \%$ in this case. Once the SSS content was raised (Figs. 6B2, 6C2 , and 6D2), additional pores appeared, associated with the burnout of the SSS, which left voids or cavities behind and created pores with size that depended upon the SSS particle size, content, and packing inside the green body, in addition to the final shrinkage (Fig. 4). Figs. 6A2, 6B2, 6C2 2, and 6D2 show that larger pores were produced as the SSS content was increased, which is in line with other works $[4,8,12,21]$. The PVA content increased as well, adding another contribution to this effect. Also, channel-like pores and/or other small pores around 1-4 $\mu \mathrm{m}$ in width can be seen in Figs. 6A3, 6B3, 6C3, and 6D3, mostly resulting from the imperfect packing of the alumina particles or the burnout of small amounts of SSS or PVA materials. Thus, small pores (down to about $1 \mu \mathrm{m}$ ) and large pores (up to about $102 \mu \mathrm{m}$, depending on the SSS content) coexisted in the samples with a non-zero SSS content, resulting in a wider pore size distribution compared with the $0 \%$ SSS sample, whose porous structure consisted of only small pores up to about $13 \mu \mathrm{m}$ (Fig. 6A2). Hence, larger pores seem to result only from the SSS addition, whereas smaller pores might be produced either by the non-ideal packing of the alumina particles or the burnout of small contents of SSS or organic binder. The increased shrinkage with the increase in the SSS content (Fig. 4), in addition to the SSS agglomeration inside the green bodies, make it difficult to relate the size of the large pores to the size of the SSS particles. However, the depicted morphology of the porous alumina product obtained through the sacrificial phase technique was consistent with the microstructural 


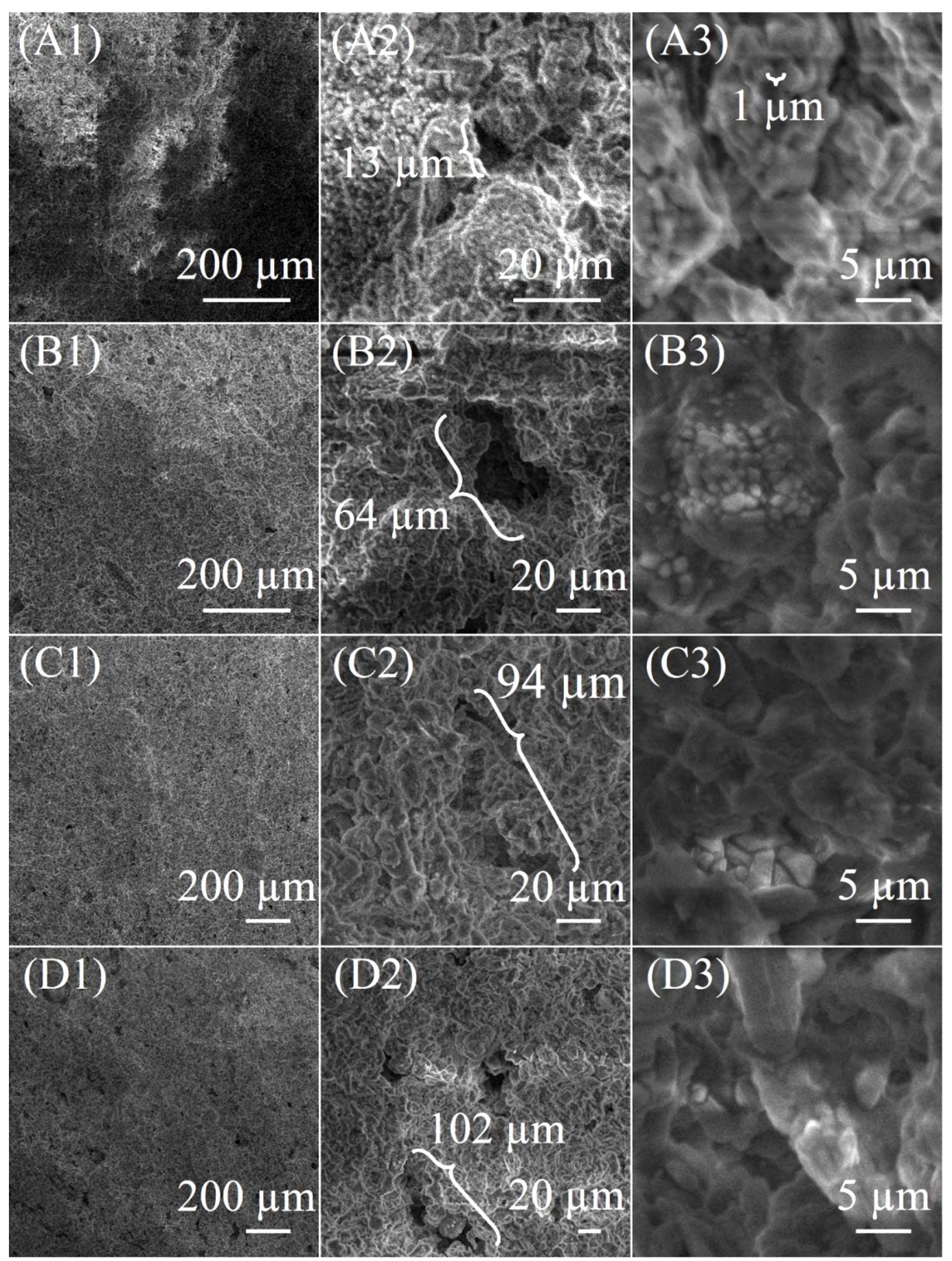

Figure 6: SEM micrographs of porous alumina ceramic samples prepared with SSS content of $0 \mathrm{wt} \%$ (A), $20 \mathrm{wt} \%$ (B), $40 \mathrm{wt} \%$ (C), and $60 \mathrm{wt} \%$ (D). [Figura 6: Micrografias de MEV de amostras de alumina porosa preparadas com teor de SSS de $0 \mathrm{wt} \%$ (A), $20 \mathrm{wt} \%$ (B), $40 \mathrm{wt} \%$ (C) e $60 \mathrm{wt} \%$ (D).]

characteristic for a negative copy of the PF material.

Indirect tensile strength: Fig. 7 demonstrates typical examples of the diametrical fracture during the Brazilian disk test for samples prepared with different SSS contents. Fig. 8 shows the results of the indirect tensile strength measurement for the prepared alumina ceramic disks. The Weibull statistics for the strengths of the alumina ceramic samples obtained from each SSS content are given in Fig. 9. Parameters of the Weibull statistics obtained for each type of the prepared porous alumina ceramics are given in Table I. The Weibull moduli given in Table I are in the range 9-46. Although these values might be overestimated (due to the small number of tested samples), especially for the case of $0 \mathrm{wt} \%$ SSS content, a mutual comparison (the general trend) suggested that the reliability of the obtained product decreased with the increase in its porosity. This was in accordance with the microstructural evaluation since pores can be considered flaws, whose size was found to increase with the increase in porosity (Figs. 5, 6A2, 6B2, $6 \mathrm{C} 2$, and $6 \mathrm{D} 2$ ). The samples prepared with a non-zero SSS 
content had low values of Weibull modulus (m) in the range 9-13, which reflected a high scattering of the indirect tensile strengths (i.e., wide distribution of flaw sizes), as opposed to the samples prepared with no SSS, which showed a very high value of 45.65 for the Weibull modulus and therefore a low scattering of the indirect tensile strength values. The mechanical strength decreased with the increase in porosity, i.e., with the decrease in bulk density, as shown in Table I and Fig. 8. This result agreed with many literature data, and it is a general trend in all porous materials, where the application of a mechanical load causes the pores to coalesce, meaning that the higher the porosity, the higher the probability of this coalescence and the larger is the resulting flaw size $[4,8,34]$. Another explanation is that the pores play the role of stress concentration sites, and they reduce the cross-sectional area of the solid phase subject to load [10,12,27]. Therefore, the increase in porosity usually leads to a reduction in strength. According to a model developed by Gibson and Ashby [8, $23,35]$, the so-called GA model, the compressive strength $\left(\sigma_{c}\right)$ of a porous material is related to its relative density $\left(\rho_{\mathrm{b}} / \rho_{\mathrm{s}}=1-\mathrm{P}\right)$, with $\mathrm{P}$ being the total porosity, according to:

$$
\frac{\sigma_{\mathrm{c}}}{\sigma_{\mathrm{f}}}=\mathrm{C} \cdot\left(\frac{\rho_{\mathrm{b}}}{\rho_{\mathrm{s}}}\right)^{\mathrm{n}}
$$

where $\sigma_{f}$ is the bending strength of the solid phase, c a geometric constant, and $\mathrm{n}$ equals 1.5 for an open-cell porous structure or ranges from 1 to 1.5 for closed-cell structures. A linear regression of the obtained data with respect to Eq. E, using a double log plot, yields $n=3.04$ and $\mathrm{c}=0.444$, with $\mathrm{R}^{2}=0.999$, where a value of $400 \mathrm{MPa}$ was assumed for the modulus of rupture $\left(\sigma_{f}\right)$ of the alumina composing the solid skeleton of the prepared porous samples [1, 23]. The calculated value of $\mathrm{n}$ was larger than the exponent 1.5 predicted by the GA model for open-cell foams, a result

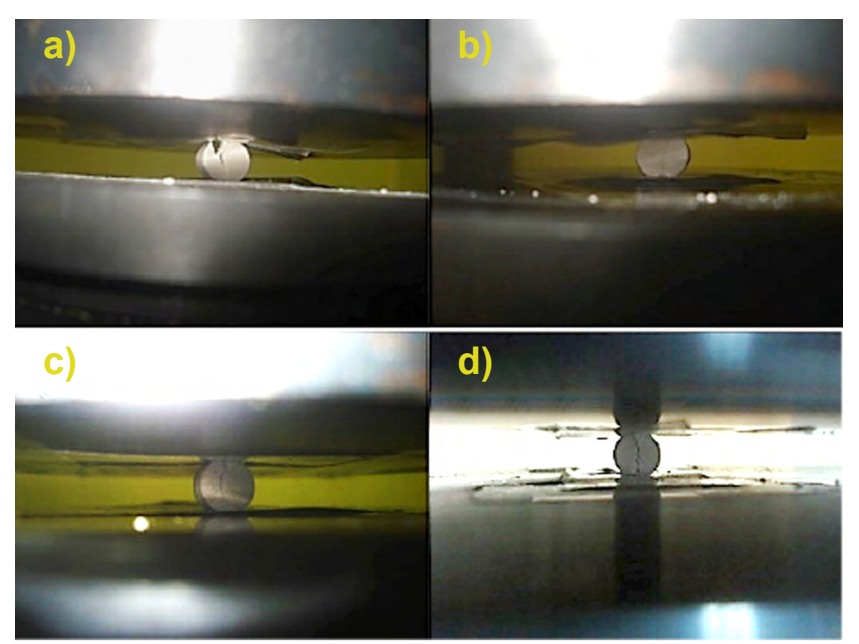

Figure 7: Images of diametrical fracture during the Brazilian disk test of porous alumina disk samples prepared with different SSS contents: a) $0 \mathrm{wt} \%$; b) $20 \mathrm{wt} \%$; c) $40 \mathrm{wt} \%$; and d) $60 \mathrm{wt} \%$.

[Figura 7: Imagens de fratura diametral durante ensaio de compressão diametral de amostras de disco de alumina porosa preparadas com diferentes teores de SSS: a) $0 \mathrm{wt} \%$; b) $20 \mathrm{wt} \%$; c) $40 \mathrm{wt} \%$; e d) $60 \mathrm{wt} \%$.]

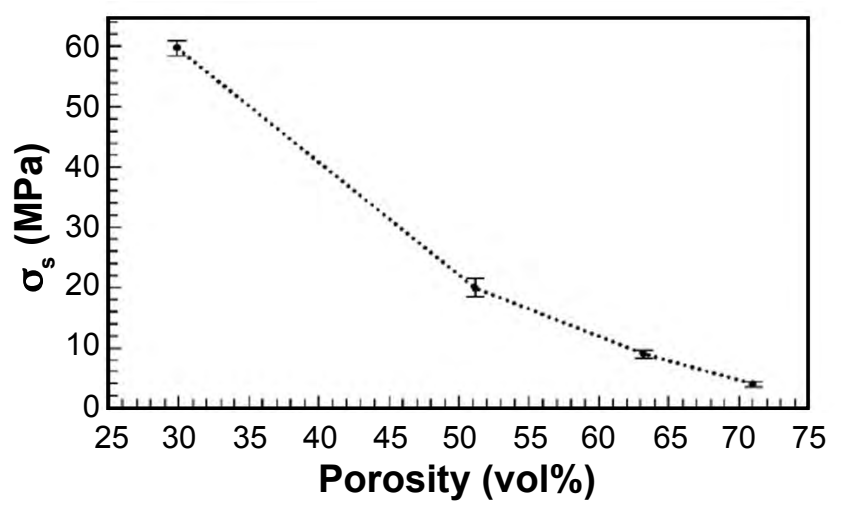

Figure 8: Brazilian disk tensile strength versus total porosity of the prepared alumina ceramics.

[Figura 8: Resistência à tração por compressão diametral versus porosidade total das cerâmicas de alumina.]

that pointed toward a rather open structure for the prepared samples. The small value of the closed porosity relative to the total porosity (Fig. 5) is in line with this result. A comparison between the theory and the experiment is presented in Table II, where the determined indirect tensile strengths of the prepared porous alumina pellets, along with the compressive strengths predicted by the GA model for porous alumina ceramics (with both open and closed cell structures $[1,36])$ are given in terms of the relative density.

Again, this comparison was consistent with the fact that the obtained porous structure of the prepared alumina ceramics was an open-cell structure, as explained earlier in Fig. 5. However, the compared data was the splitting tensile strength, measured using the Brazilian disk test, and not the compressive strength, considered by the GA model in Eq. E. A fracture mechanics analysis was applied to the GA model, which allowed to obtain the following expression for the tensile strength $\left(\sigma_{t}\right)$ of a cellular structure or foam:

$$
\frac{\sigma_{t}}{\sigma_{f}}=c^{\prime} \cdot \sqrt{\frac{L}{R}} \cdot\left(\frac{\rho_{b}}{\rho_{s}}\right)^{1.5}
$$

where c' is a dimensionless geometric constant, $\mathrm{L}$ is the foam cell size, and $\mathrm{R}$ is the critical or macroscopic flaw size. Eq. $F$ is valid only when $L \leq R$, with equality, if the foam is intact (i.e., flaw-free). The values of $\mathrm{c}$ and c' are approximately the same (about 0.2) [1, 23,37]. This means that the tensile and compressive strengths are equal for an intact open-cell foam (i.e., when $\mathrm{L}=\mathrm{R}$ and $\mathrm{n}=1.5$ ). In light of this argument, and due to the comparable values of the experimental results of the splitting tensile strength and the theoretical compressive strength expected by the GA model for an open-cell porous structure, as revealed by Table II, it seems reasonable to deduce that the prepared alumina samples may be intact. This is consistent with the general aspect of porous ceramics produced by the sacrificial phase method, i.e., constituting a negative copy of the PF with no flaws being caused by its removal. However, due to the absence of a well-defined cell (i.e., a cellular structure, in a sense dealt in the GA model) as the SEM micrographs in Fig. 6 showed, it became difficult to interpret these results with the aid of this model. In fact, this 

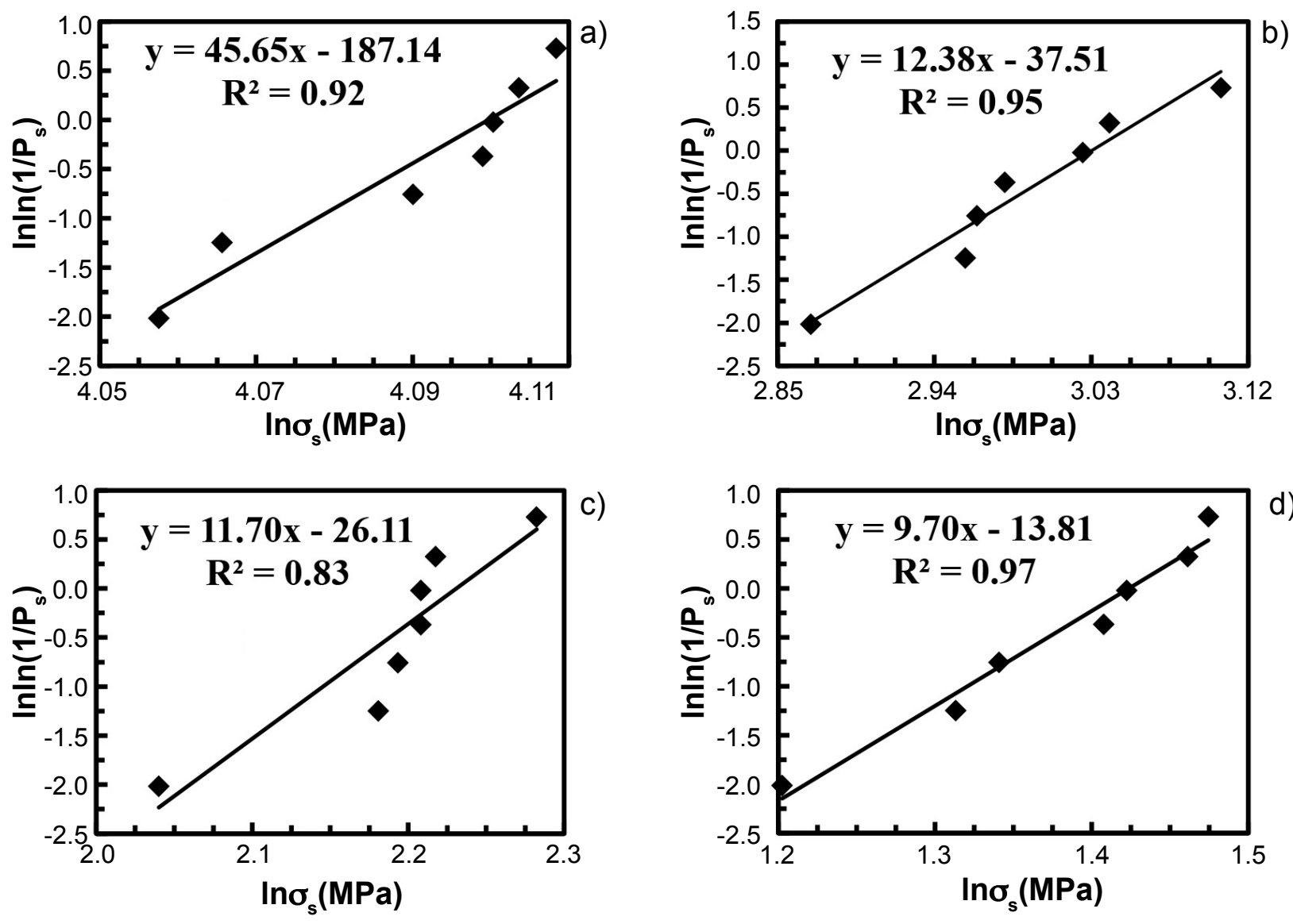

Figure 9: Weibull plots for the tensile strength data of the porous alumina samples prepared with SSS content of $0 \mathrm{wt} \%$ (a), $20 \mathrm{wt} \%$ (b), 40 wt\% (c), and $60 \mathrm{wt} \%$ (d).

[Figura 9: Gráficos de Weibull para os dados de resistência à tração das amostras de alumina porosas preparadas com teor de SSS de 0 $w t \%(a), 20 w t \%(b), 40 w t \%(c)$ e $60 w t \%(d)$.

morphology might be the reason behind the largeness of the obtained value of $n$. Furthermore, it must be noticed that the mechanical property involved in the previous discussion is the 'indirect tensile' rather than the 'tensile' strength. The relatively small difference between the indirect tensile strength of the prepared alumina samples and the theoretical compressive strength predicted by the GA model was exceptional to the accepted rule stating that the latter is at least one order of magnitude higher than the former [37-39], but it revealed the higher mechanical properties achievable by the sacrificial phase route, as compared to other methods used for the preparation of porous ceramics. A more generalized formula of Eqs. $\mathrm{E}$ and $\mathrm{F}$ is based on expressing the dependence of some properties of porous materials, including mechanical, thermal, and electrical, on their fractional (or relative) density ratio $\rho_{\mathrm{b}} / \rho_{\mathrm{s}}$, as a powerlaw function of the form: property $=\mathrm{f}\left[\left(\rho_{\mathrm{b}} / \rho_{\mathrm{s}}\right)^{\mathrm{k}}\right]$, where $\mathrm{k}$ is between 1 and 3 [40]. Another modeling for the relation between porosity and several properties of porous materials is described by what is called 'minimum solid area' or MSA model. This model predicts an exponential dependence of property on porosity. In particular, the MSA model gives the following expression for mechanical properties, known as Rice's formula:

$$
\sigma=\sigma_{d} \cdot e^{-b . P}
$$

where $\mathrm{P}$ is the porosity, $\sigma$ is the strength of the material with porosity $\mathrm{P}, \sigma_{\mathrm{d}}$ is the strength of the dense material (i.e., with zero porosity), and $\mathrm{b}$ is a parameter characterizing the porous structure of the material $[9,34,41]$. The approach adopted by the MSA model is based on equating the fraction of the property at zero porosity, as a function of the porosity $\mathrm{P}$, with the minimum solid area fraction of the total area of the porous material normal to a given reference axis, such as stress. The underlying assumption is that porous materials (or bodies) may be ideally constructed by stacking of 2 basic types of identical features: partially bonded solid spheres (i.e., particles), and spherical bubbles or pores within a solid matrix. The model expects that most real porous structures may be represented by a combination of these two types of geometry [41]. The value of factor $b$ in Rice's formula (Eq. G) depends on this combination, i.e., the contribution of each feature type and its stacking. For instance, $b=3$ if the pore structure may be represented by cubic stacking of bubbles (i.e., spherical pores), $b=5$ corresponds to cubic stacking of solid spheres, whereas a value between 3 and 5 would characterize a mixture of bubbles and solid spheres, both cubically stacked. Treatment of the present data with respect 
Table I - Porosity, average splitting tensile strength $\left(\sigma_{s}\right)$, and Weibull statistics parameters (m - Weibull modulus, $\sigma_{0}$ characteristic strength) of the prepared alumina ceramics.

[Tabela I - Porosidade, resistência à tração média por compressão diametral $\left(\sigma_{s}\right)$ e parâmetros de Weibull $(m$ - módulo de Weibull, $\sigma_{0}$ - resistência característica) das cerâmicas de alumina.]

\begin{tabular}{cccccc}
\hline SSS content $(\mathrm{wt} \%)$ & No. of samples & Porosity $(\mathrm{vol} \%)$ & $\sigma_{\mathrm{s}}(\mathrm{MPa})$ & $\mathrm{m}$ & $\sigma_{0}(\mathrm{MPa})$ \\
\hline 0 & 7 & $29.9 \pm 0.7$ & $59.7 \pm 1.2$ & 45.6 & 60.3 \\
20 & 7 & $51.2 \pm 1.4$ & $20.0 \pm 1.5$ & 12.4 & 20.7 \\
40 & 7 & $63.2 \pm 0.9$ & $9.0 \pm 0.6$ & 11.7 & 9.3 \\
60 & 7 & $71.0 \pm 0.9$ & $4.0 \pm 0.4$ & 9.7 & 4.2 \\
\hline
\end{tabular}

Table II - Indirect tensile strengths of the prepared alumina samples and compressive strengths predicted by the GA model for open and closed cell porous alumina ceramics for the same values of relative density.

[Tabela II - Resistências à tração indiretas das amostras de alumina e resistências à compressão previstas pelo modelo GA para cerâmicas de alumina porosas de células abertas e fechadas para os mesmos valores de densidade relativa.]

\begin{tabular}{ccccc}
\hline $\begin{array}{c}\text { SSS ratio } \\
(\mathrm{wt} \%)\end{array}$ & Relative density & $\begin{array}{c}\text { Splitting tensile strength - } \\
\text { measured (MPa) }\end{array}$ & \multicolumn{2}{c}{ Compressive strength - GA model (MPa) } \\
Open-cell foam & Closed-cell foam \\
\hline 0 & $0.70 \pm 0.01$ & $59.7 \pm 1.2$ & 47.0 & 280.4 \\
20 & $0.49 \pm 0.01$ & $20.0 \pm 1.5$ & 27.3 & 195.4 \\
40 & $0.37 \pm 0.01$ & $9.0 \pm 0.6$ & 17.8 & 147.1 \\
60 & $0.29 \pm 0.01$ & $4.0 \pm 0.4$ & 12.5 & 115.9 \\
\hline
\end{tabular}

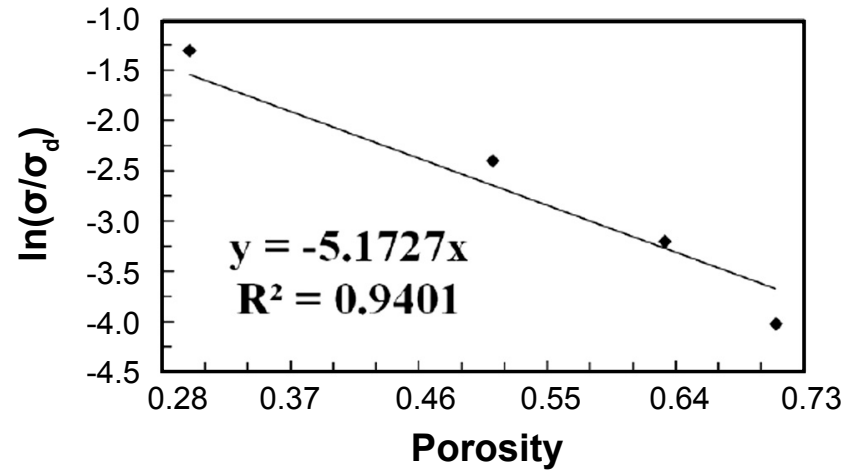

Figure 10: Relative splitting tensile strength curve of the prepared alumina pellets fitted with Rice's formula.

[Figura 10: Curva de resistência à tração relativa das pastilhas de alumina ajustada com a fórmula de Rice.]

to Eq. G, using linear regression in a semi-log plot, as shown in Fig. 10, yielded $b=5.17$, with $R^{2}=0.94$, where a value of $220 \mathrm{MPa}$ for the tensile strength of dense alumina $\left(\sigma_{\mathrm{d}}\right)$ was utilized [24]. The obtained value for $b$ suggested that the pore structure of the prepared samples might be represented by one type of geometry, namely solid spheres or particles, which are partially bonded by a combination or mixture of two kinds of stacking: the first being cubic and comprising the main component, and the second is a rhombic stacking making up only a little portion of the mixed stacking. According to the MSA model, it seems that no spherical pores were needed for the description of the obtained porous structure, although this is somewhat inconsistent with the range of porosities obtained, especially for $\mathrm{P}>50 \mathrm{vol} \%$ [41]. This might be attributed to the strict constraint of the model concerning the assumption of a uniform cell size, which is not satisfied in reality, as confirmed, for instance, by the microstructures shown in Fig. 6.

Fig. 11 presents a comparison between the splitting tensile strengths of porous alumina ceramic pellets prepared by uniaxial pressing and space holder method but using 5 different types of PFs: primary batteries graphite waste, active yeast, commercial rice husk ash [12], naphthalene

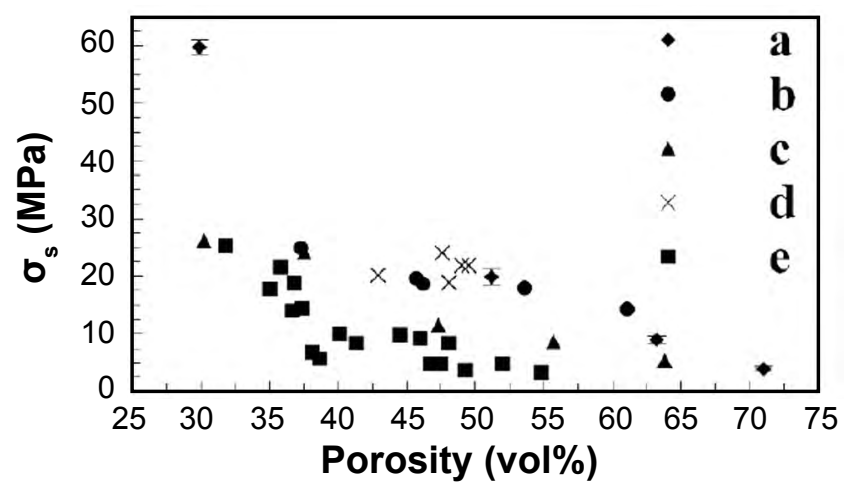

Figure 11: Indirect tensile strength measured by the Brazilian disk test for porous alumina ceramics prepared by the sacrificial phase method with different pore formers (PFs): a) sunflower seed shells (this study); b) graphite waste [12]; c) active yeast [12]; d) commercial rice husk ash [12]; and e) naphthalene [21].

[Figura 11: Resistência à tração indireta medida pelo ensaio de compressão diametral para cerâmicas porosas de alumina preparadas pelo método da fase de sacrifício com diferentes formadores de poros: a) cascas de sementes de girassol (este estudo); b) resíduo de grafita [12]; c) levedura ativa [12]; d) cinza comercial de casca de arroz [12]; e e) naftaleno [21].] 
[21], and sunflower seed shells (this study). It was clear that a wide range of porosity, with high levels of mechanical properties, was achieved for the porous alumina ceramics prepared with sunflower seed shells as the pore-forming agent. Furthermore, it might be useful to report that this result holds even though the alumina samples prepared in this study were sintered at $1500{ }^{\circ} \mathrm{C}$, which was lower than the 1550 and $1600{ }^{\circ} \mathrm{C}$ used in the mentioned studies [12, 21].

Volume electrical resistivity: the results of the volume resistivity measurement of 4 selected samples as a function of their porosity are shown in Table III. The increase in the volume electrical resistivity as the porosity increased was in accordance with the literature $[4,35]$. Resistivity is the reciprocal of electrical conductivity. Many models describing the relationship between porosity and electrical conductivity of porous materials may be found in the literature [41-46]. Although some of them focus mainly on porous metals, they all indicate that the electrical conductivity of porous materials decreases as the relative density decreases (i.e., the resistivity would increase by increasing porosity). Two models were chosen and found useful to draw meaningful conclusions when applied to the data presented in Table III, the MSA model and the model used in [42], which gives the following expression for the effective electrical conductivity of a porous material versus porosity:

$$
\mathrm{K}=\mathrm{K}_{\mathrm{d}} \cdot(1-\mathrm{w} \cdot \mathrm{P})
$$

where $\mathrm{K}$ denotes the conductivity, and the subscript $\mathrm{d}$ corresponds to dense material. The $\mathrm{w}$ term is expected to vary between 1 and 2, provided that the pores inside the material are spherical. Table III shows the calculated value of this w term, for each of the 4 porous alumina ceramic samples tested for the electrical resistivity, where a value of $10^{14} \Omega . c m$ for the resistivity of dense alumina was adopted [4]. Clearly, the two samples prepared with a PF content of 10 and $15 \mathrm{wt} \%$ yielded a w value between 1 and 2, as predicted by the theoretical model. However, in the case of the samples prepared with 0 and $5 \mathrm{wt} \% \mathrm{PF}$ content, the $\mathrm{w}$ value was outside the indicated range. A possible explanation is related to the fact that the model described by Eq. $\mathrm{H}$ assumes a spherical pore structure (after the solid skeleton attaining full density). This condition is expected to be difficult to achieve for the high open porosity alumina ceramic sample prepared with $0 \mathrm{wt} \% \mathrm{PF}$ and sintered at a moderately low temperature of $1500{ }^{\circ} \mathrm{C}$. Similarly, it seems that full density was not attained in the case of the sample prepared with a $5 \mathrm{wt} \%$ PF content, as opposed to the remaining two samples prepared with 10 and $15 \mathrm{wt} \% \mathrm{PF}$, where the amounts of impurities introduced by the SSS material were sufficient to promote densification of the solid skeleton. Fig. 12 shows the measured results of electrical conductivity and the curve fitted with the exponential relationship of the MSA model (Eq. I), which is Rice's formula of Eq. G with
Table III - Volume electrical resistivity measured at room temperature and porosity of sintered alumina ceramic disks prepared with different SSS content at a compaction pressure of $38 \mathrm{MPa}$.

[Tabela III - Resistividade elétrica volumétrica medida à temperatura ambiente e porosidade de discos sinterizados de alumina preparados com diferentes teores de SSS a uma pressão de compactação de $38 \mathrm{MPa}$.]

\begin{tabular}{cccc}
\hline $\begin{array}{c}\text { SSS } \\
\text { content } \\
(\mathrm{wt} \%)\end{array}$ & $\begin{array}{c}\text { Porosity } \\
(\mathrm{vol} \%)\end{array}$ & $\begin{array}{c}\text { Volume resistivity } \\
\left(\mathrm{x} 10^{15} \Omega . \mathrm{cm}\right)\end{array}$ & $\mathrm{w}$ \\
\hline 0 & 39.7 & 1.4 & 2.34 \\
5 & 47.2 & 4 & 2.06 \\
10 & 54.5 & 10 & 1.82 \\
15 & 58.3 & 15 & 1.70 \\
\hline
\end{tabular}

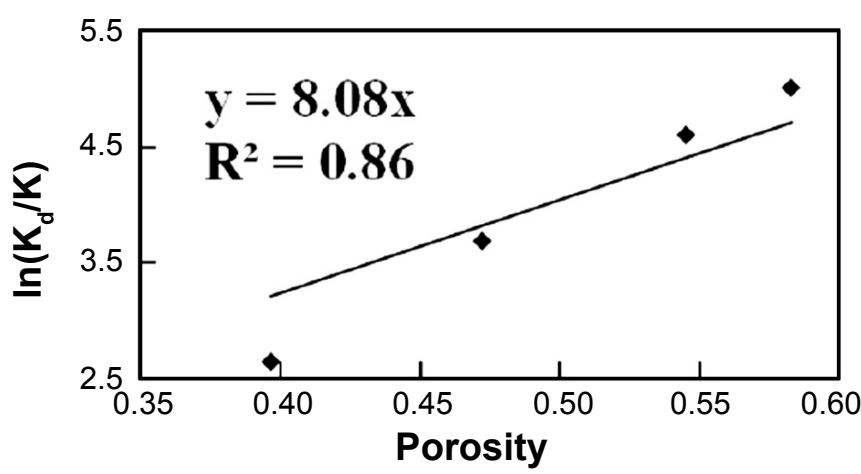

Figure 12: Relative electrical conductivity curve of alumina ceramic disks fitted with Rice's formula.

[Figura 12: Curva de resistividade volumétrica relativa de discos de alumina ajustada com a fórmula de Rice.]

$\sigma$ being replaced with $\mathrm{K}$ (volume electrical conductivity) and $b$ with $b^{\prime}$ :

$$
\mathrm{K}=\mathrm{K}_{\mathrm{d}} \cdot \mathrm{e}^{-\mathrm{b}^{\prime} \cdot \mathrm{P}}
$$

From Fig. 12, a characteristic coefficient of b'=8.08 was obtained, with a coefficient of determination of $\mathrm{R}^{2}=0.86$. According to [41], the obtained value of b' would correspond to an array of pores, which may be reasonably represented by the solid spherical particle geometry, partially bonded together through a combination of cubic and rhombohedral stacking. This is interesting since it is nearly the same porous structure obtained when interpreting the mechanical properties with the MSA model (Fig. 10). The larger value of b' compared to b may be related to a larger portion of the solid spheres being rhombohedrally stacked, and this may be connected to the difference in the conditions under which the two groups of samples were prepared, especially the compaction pressure. The model developed in [43] could not be fully used, as it requires a sufficiently accurate measurement of the tap porosity of the starting powder, which in the present study was a mixture of transformed and nontransformed alumina phases, and SSS residues. 


\section{CONCLUSIONS}

Macroporous alumina ceramics have been successfully prepared by the space holder technique, using sunflower seed shells as the fugitive template material, which is a natural, cheap, and widely available waste material. The green bodies were formed by uniaxial dry pressing. Physical and mechanical properties of the sintered porous alumina ceramics, along with its microstructure, were studied in the function of the sunflower seed shells content in the green bodies. Electrical properties were investigated as well. Sunflower seed shells proved to be a promising pore-forming agent, compared to other types of fugitive materials, in terms of the wide range of porosity produced (extending from 30 up to $71 \mathrm{vol} \%$ ) and the corresponding high mechanical strengths attained (splitting tensile strength within 4-60 MPa). Volume electrical resistivity as high as $15 \times 10^{15} \Omega . c m$ was obtained for the sample with $58.3 \mathrm{vol} \%$ porosity. Experimental mechanical results were consistent with the Gibson-Ashby model. Electrical resistivity results were consistent with literature data for porous alumina ceramics. Porosity could be increased by increasing the SSS content up to $60 \mathrm{wt} \%$, and a further increase seems to be possible since no limiting effect due to the shrinkage was observed. The porosity of the prepared porous alumina ceramics is mainly open. Hence, the specific potential applications are in the field of filtration of hot and corrosive liquids and gases, as well as catalyst supports. Also, the samples with high mechanical strength may be useful as lightweight structural materials and grinding tools, whereas those with good insulating properties are typical for electrical applications. Another potential application is in the field of thermal insulation. The use of solid pore formers complies well with the conventional solid-state processing of ceramic materials without any further complication.

\section{ACKNOWLEDGMENTS}

The authors would like to acknowledge the Higher Institute for Applied Sciences and Technology (HIAST) and the Department of Physics for their financial support and facilities.

\section{REFERENCES}

[1] A.R. Studart, U.T. Gonzenbach, E. Tervoort, L.J. Gauckler, J. Am. Ceram. Soc. 89, 6 (2006) 1771.

[2] K. Ishizaki, S. Komarneni, M. Nanko, Porous materials: process technology and applications, Springer, USA (1998).

[3] M.A.A.M. Nor, L.C. Hong, Z.A. Ahmad, H.M. Akil, J. Mater. Process. Technol. 207, 1-3 (2008) 235.

[4] R.M. Khattab, M.M.S. Wahsh, N.M. Khalil, Ceram. Int. 38, 6 (2012) 4723.

[5] K. Huang, Y. Li, Y. Zhao, S. Li, Y. Li, S. Sang, Mater. Lett. 165 (2016) 19.

[6] J. Luyten, S. Mullens, J. Cooymans, A.M.D. Wilde, I. Thijs, R. Kemps, J. Eur. Ceram. Soc. 29, 5 (2009) 829.
[7] P. Colombo, Philos. Trans. R. Soc. A 364 (2006) 109.

[8] B.V.M. Kumar, Y.W. Kim, Sci. Technol. Adv. Mater. 11, 4 (2010) 44303.

[9] G. Liu, "Fabrication of porous ceramics and composites by a novel freeze casting process", PhD Thesis, Un. Birmingham (2011) 3 .

[10] R. Ahmad, J.H. Ha, I.H. Song, J. Kor. Powd. Met. Inst. 21, 5 (2014) 389.

[11] Z. Živcová, E. Gregorová, W. Pabst, Process. Appl. Ceram. 2, 1 (2008) 1.

[12] M.S. Ali, M.A.A. Hanim, S.M. Tahir, C.N.A. Jaafar, M. Norkhairunnisa, K.A. Matori, J. Ceram. Soc. Jpn. 125, 5 (2017) 402.

[13] G.C. Ribeiro, B.A. Fortes, L. da Silva, J.A. Castro, S. Ribeiro, Cerâmica 65, Suppl 1 (2019) 70.

[14] P.F. Cancalon, J. Am. Oil Chem. Soc. 48, 10 (1971) 629.

[15] H. Haykiri-Acma, A.Z. Turan, S. Yaman, S. Kucukbayrak, Fuel Process. Technol. 91, 11 (2010) 1569.

[16] H. Haykiri-Acma, S. Yaman, in Proc. World Renew. Energy Cong. Bioenergy Technol., Linköping (2011) 251.

[17] K. Salasinska, M. Polka, M. Gloc, J. Ryszkowska, Polymer 61, 4 (2016) 255.

[18] C. Cosereanu, L.M. Brenci, O. Zeleniuc, A. Fotin, BioResources 10, 1 (2015) 1127.

[19] M. Shahbandeh, "Sunflower seed production in major countries 2018/19”, Statista, New York (2020), https://www. statista.com.

[20] A. Boumaza, L. Favaro, J. Lédion, G. Sattonnay, J.B. Brubach, P. Berthet, A.M. Huntz, P. Roy, R. Tétot, J. Solid State Chem. 182, 5 (2009) 1171.

[21] S. Surabhi, "Production of alumina based porous ceramics using naphthalene as the pore former", Bach. Thesis, Nat. Inst. Technol., Rourkela (2012).

[22] J. Yu, X. Sun, Q. Li, X. Li, Y. Liu, K. Duan, Adv. Mater. Res. 42 (2008) 265.

[23] A.R. Jamaludin, S.R. Kasim, A.K. Ismail, M.Z. Abdullah, Z.A. Ahmad, J. Eur. Ceram. Soc. 35, 6 (2015) 1905 .

[24] K. Davis, School Dr. Stud. European Union J. 2 (2010) 109.

[25] ASTM C20-00, "Standard test methods for apparent porosity, water absorption, apparent specific gravity, and bulk density of burned refractory brick and shapes by boiling water", ASTM (2010).

[26] D. Li, L.N.Y. Wong, Rock. Mech. Rock. Eng. 46, 2 (2013) 269.

[27] B.S.M. Seeber, U.T. Gonzenbach, L.J. Gauckler, J. Mater. Res. 28, 17 (2013) 2281.

[28] ASTM D 3967-95a, "Standard test method for splitting tensile strength of intact rock core specimens", ASTM (2001).

[29] M.V. Silva, D. Stainer, H.A. Al-Qureshi, O.R.K. Montedo, D. Hotza, J. Ceram. 2014 (2014) 618154.

[30] D.W. Richerson, Modern ceramic engineering: properties, processing, and use in design, $2^{\text {nd }}$ ed., Marcel Dekker, New York (1992). 
[31] V. Sciamanna, B.N. Ali, M. Gonon, Ceram. Int. 41, 2 (2015) 2599.

[32] ASTM D257-07, "Standard test methods for dc resistance or conductance of insulating materials", ASTM (2007).

[33] P.S. Santos, H.S. Santos, S.P. Toledo, Mater. Res. 3, 4 (2000) 104.

[34] J.H. Eom, Y.W. Kim, S. Raju, J. Asian. Ceram. Soc. 1, 3 (2013) 220.

[35] L.J. Gibson, M.F. Ashby, Cellular solids: structure and properties, $2^{\text {nd }}$ ed., Cambridge Un. Press, UK (1997).

[36] C. Tallon, C. Chuanuwatanakul, D.E. Dunstan, G.V. Franks, Ceram. Int. 42, 7 (2016) 8478.

[37] R. Brezny, D.J. Green, J. Am. Ceram. Soc. 76, 9 (1993) 2185.

[38] L. Montanaro, Y. Jorand, G. Fantozzi, A. Negro, J. Eur.
Ceram. Soc. 18, 9 (1998) 1339.

[39] R.W. Rice, J. Mater. Sci. 32, 17 (1997) 4731.

[40] B.C. Nicolat, T. Fey, P. Greil, Adv. Eng. Mater. 12, 9 (2010) 884.

[41] R.W. Rice, J. Mater. Sci. 31, 1 (1996) 102.

[42] R.M. German, Sintering: from empirical observations to scientific principles, Elsevier, USA (2014).

[43] J.M. Montes, F.G. Cuevas, J. Cintas, Appl. Phys. A 92, 2 (2008) 375.

[44] P.S. Liu, T.F. Li, C. Fu, Mater. Sci. Eng. A 268, 1-2 (1999) 208.

[45] F.G. Cuevas, J.M. Montes, J. Cintas, P. Urban, J. Porous Mater. 16, 6 (2009) 675.

[46] M. Hakamada, T. Kuromura, Y. Chen, H. Kusuda, M. Mabuchi, Mater. Trans. 48, 1 (2007) 32.

(Rec. 12/09/2019, Rev. 17/12/2019, Ac. 31/01/2020) 